\title{
Lumen
}

Selected Proceedings from the Canadian Society for Eighteenth-Century Studies

\section{Whig and Tory Panegyrics: Addison's The Campaign and Philips's Bleinheim Reconsidered}

\section{John D. Baird}

Volume 16, 1997

Freedom and Boundaries

Émancipation et frontières

URI : https://id.erudit.org/iderudit/1012447ar

DOI : https://doi.org/10.7202/1012447ar

Aller au sommaire du numéro

Éditeur(s)

Canadian Society for Eighteenth-Century Studies / Société canadienne d'étude du dix-huitième siècle

ISSN

1209-3696 (imprimé)

1927-8284 (numérique)

Découvrir la revue

Citer cet article

Baird, J. D. (1997). Whig and Tory Panegyrics: Addison's The Campaign and Philips's Bleinheim Reconsidered. Lumen, 16, 163-177.

https://doi.org/10.7202/1012447ar d'utilisation que vous pouvez consulter en ligne. 


\section{Whig and Tory Panegyrics: Addison's The Campaign and Philips's Bleinheim Reconsidered}

Of the more than forty poems written to celebrate the battle of Blenheim only two can be said to have had more than ephemeral appeal to readers: Joseph Addison's The Campaign and John Philips's Bleinheim (Horn, Marlborough 41). ${ }^{1}$ Both poems were reprinted frequently through the eighteenth century, but they have since fallen by the wayside of literary history; they have no place in current anthologies, and have attracted little recent commentary. They remain, nevertheless, distinctly superior to the common run of eighteenth-century political panegyric, and the contrasts which they exhibit when considered as a pair have real significance as indicators of larger cultural movements. And they are a pair, not fortuitously through the winnowing of time, but by their origins although subsequent literary history, beginning with Johnson's account in his life of Philips, has tended to distort their relationship. This essay proposes to review and correct received opinion about the origins and historical relationship of these two poems, and to assess their contemporary importance as contributions to political debate. Finally, it will examine their more enduring significance as documents reflecting a substantive shift in the cultural movements which shaped literary discourse.

There are two rival narratives of the origin of The Campaign, one given by Thomas Tickell in his 1721 edition of Addison's works, the other by Eustace Budgell in his Memoirs of the Boyles of 1732. Budgell's is much the longer and more circumstantial, and has not surprisingly tended to dominate later versions. Fifty years ago Robert Horn examined these conflicting accounts, and concluded that the story told by Thomas Tickell was essentially correct, and that Budgell's rival story was mostly just that: a story. ${ }^{2}$ Horn's objective was to demolish Macaulay's essay on Addison, in which Macaulay, with many picturesque embellishments, blends a little Tickell with a lot of Budgell to create a yarn as misleading 
as it is memorable. Samuel Johnson, in his life of Addison in the Lives of the English Poets, was an earlier follower of Budgell, and his version remains influential for modern scholars. It is not necessary to follow the details of Horn's exhaustive critique of Budgell; the essential points of Tickell's account as confirmed by Horn are these: that Addison had completed about two-thirds of The Campaign by the end of October 1704; that about that time Lord Treasurer Godolphin saw the incomplete draft and was so pleased with it that he appointed Addison immediately to the Commissionership of Appeals conveniently vacated a few days earlier by the death of John Locke; ${ }^{3}$ and that publication of the poem, first announced in the press for mid-November, was postponed to coincide with Marlborough's return to England from the Continent. It was published on December 14, 1704, the day Marlborough landed at Greenwich and was received by Queen Anne at St. James's (Horn, 'Addison's' 893). To mark that day, the formal conclusion of Marlborough's 1704 campaign, Addison published a panegyric on the campaign dedicated to Marlborough himself, a panegyric for which he had already been liberally rewarded by the 'prime minister' of the day.

Modern discussions of the origin of Philips's poem seem to follow and extrapolate from Johnson's brief statement on the matter in his life of Philips. Philips, he says, was 'probably with an occult opposition to Addison, employed to deliver the acclamations of the Tories'(1:313). The implicit suggestion here is that Bleinheim, which is addressed to Robert Harley, was only undertaken after The Campaign was published, as a kind of Tory antidote. Later writers have turned this suggestion into a fact. Horn writes that Addison's poem 'did not satisfy official Tory sentiment. Hence John Philips was commissioned to produce the Tory response in his Bleinheim' ('Addison's' 902), and calls Bleinheim 'a retort to Addison's Campaign' (Marlborough 106). Frank Ellis, in a note in Poems on Affairs of State, explains that Philips 'was drafted to write the Tory counterpart to The Campaign' (166). In the only recent substantial discussion of Bleinheim, Dustin Griffin says that it was commissioned 'to match' The Campaign ('Bard' 449).

The dates of publication make it difficult to accept this received opinion that Philips was engaged only after Addison's poem had appeared. The Campaign was published on December 14; Philips's poem was published less than three weeks later, on January 3,1704/05, the day of Marlborough's victory parade from the Tower of London to St. James's Park. It is of course possible that a poet could have been found to compose a poem of nearly 500 lines, and have it printed, within that space of time. It is unlikely, however, that Philips could have been that poet. In the first place, his contemporary biographer, George Sewell, whose brief life was first published in 1712, emphasizes that Philips was 
an Oxford scholar, not a Grub Street hack, and describes him as a slow composer of verses, self-critical to a fault. Furthermore, Sewell does not mention Addison's poem as the occasion of Bleinheim. 'The Reason of his coming to Town [i.e., from Oxford], was the Persuasion of some great Persons, who engaged him to write upon the Battle of BLEINHEIM;' writes Sewell (xi); he tells us also that Philips 'would willingly have declined that Undertaking, had not the powerful Incitements of his Friends prevailed upon him, to give up his Modesty to their Judgment (xv-xvi).

In any case, there is some contemporary evidence which suggests Philips began work much earlier. He tells us at the end of Bleinheim that it was written at Bucklebury, Henry St. John's country seat in Berkshire, 'where warbling Birds provoke/The Silent Muse' (481-2) — not, then, in late December. This might be merely conventional language, as to both birds and Philips's lack of fluency, but it is confirmed by another poem. Philips's Latin ode to St. John testifies to shared domestic pleasures of drinking and smoking which would have been possible in the late summer and early fall of 1704, when St. John was frequently at Bucklebury, but not during the hectic Parliamentary session of the last weeks of $1704 .{ }^{5}$ I suggest therefore that the notion of The Campaign as the prior Whig poem and Bleinheim as the subsequent Tory rejoinder to it is untenable and needs to be replaced.

First, there is the curious fact, commonly overlooked in discussions of Philips, that his poem was just as much a governmentally-sponsored effort as was Addison's. The beginning of Queen Anne's reign was a time when politicians pursued with particular energy that will-o'-the-wisp of eighteenth-century politics, the idea of a monarch and a ministry above party. This was one of the times when, in the words of the Vicar of Bray, 'Moderate men looked big, sir.' ${ }^{\prime 6}$ In April 1704, the Earl of Nottingham, highest of High Tories, had been forced out of office, taking with him a number of lesser supporters. Their places were filled by politicians who presented themselves as 'Moderate' men, more concerned to carry on the Queen's government than to indulge in party strife. The archetypal Moderate man was Robert Harley, Tory, Speaker of the House of Commons and adroit manipulator of the popular press, who became Secretary of State for the Northern Department, responsible for diplomatic relations with northern Europe, including the Netherlands and the Holy Roman Empire, both crucially involved in the campaign of 1704. Harley brought with him into the Ministry a former Tory firebrand who, at least in part for reasons of personal ambition, was willing to shelve his partisan zeal in exchange for office: Henry St. John, who became Secretary at War. Harley and St. John were thus in charge of the relevant English diplomatic and military ministries during the period of Marlbor- 
ough's 1704 campaign, cooperating regularly with Lord Treasurer Godolphin and with Marlborough's staff. St. John in particular was an admirer of Marlborough, who remained on good terms with him even after 'Moderation' collapsed in 1708 (Dickinson 48, 59). It is thus entirely misleading to suggest, by the epithet 'Tory,' that Philips's patrons were bitter inhabitants of the political wilderness. They were chief ministers of the crown, whose activities had contributed to Marlborough's victory.

Though they might profess moderation as the price of holding office in 1704, Harley and St. John had risen to power through the ranks of the Tory party, and, as events were to show, they had no intention of abandoning it. It would be very natural, therefore, for them to seek to put a Tory spin on the great victory when the news arrived in the middle of August. And so they did. They selected John Philips, an Oxford student with little money and an accomplished Latinist, whose parody of Milton's style, the mock-epic fragment The Splendid Shilling, had first appeared in print three years before. Philips came of a non-juring family and had Jacobite friends - no wonder he was reluctant to praise Marlborough, whose desertion of James II in 1688 had contributed so crucially to that monarch's fall. No wonder, too, that Philips should later be ashamed of having written the poem, at least among his Tory and Jacobite friends. ${ }^{7}$ Although the prospect of a financial reward was probably one reason why the notoriously impecunious Philips overcame his reluctance to write his poem to Harley's and St. John's orders, he did much less well than Addison, being paid one hundred pounds out of the secret service fund 'for writing a poem in blank verse of the battle of Bleinheim' (Foxon 1: 570). ${ }^{8}$

Godolphin no doubt got wind of the fact that an Oxford scholar of non-juring reputation was living at Bucklebury under St. John's eye and writing a poem on the battle, and wished to counter the potentially factious effects of this opus. How fortunate that Mr. Addison, also an Oxford scholar noted for his Latin verses, but happily a man of Whiggish sympathies, should be already at work on a poem on the same subject, a partial draft of which turned out to be both politically judicious and poetically admirable. The virtual sinecure so opportunely made available by the death of the arch-Whig Locke could hardly be conferred on a more deserving person. Addison was then assisted by a pre-publication campaign of puffery in an ad-hoc periodical, the Diverting Post, to which Richard Steele contributed a fulsome imitation of an ode by Horace: 
Shou'd Addison's Immortal Verse

Thy Fame in Arms, great Prince, Rehearse,

With Anna's Lightning you'd appear,

And glitter o'er again in War....

Addison's rich appointment was likewise announced in the Diverting Post to emphasize the official status of his forthcoming poem, which, with last-minute additions, was published on the very day when it would have maximum effect, the day of Marlborough's return to England with prisoners and captured standards. ${ }^{9}$ The production of Philips's tardier muse was ready three weeks later for the next great public occasion, the victory parade through London on January 3, but Addison's poem likely gained some propaganda advantage by being first in the field.

What was the Tory spin that Harley and St. John wanted on the battle of Blenheim? Was it not a great victory, a crushing blow to Louis XIV's plans, to French arms, and French military prestige? Yes, and it had come in the nick of time, after a long period of apparent stalemate in a Continental war which the country squires who formed so large a component of the Tory party deplored. As J. A. Downie has written: 'Until the victory at Blenheim that summer, popularity for the war was rapidly vanishing. The tory squire did not want to pay his taxes. For these reasons it was essential for the ministry to appeal to public opinion. This, at any rate, was Harley's view' (65). ${ }^{10}$ Tories were deeply suspicious of land wars in Europe. They caused English interests to be tangled with the affairs of unreliable allies who demanded subsidies to keep their armies in the field, and they led to no tangible advantage. Relatively inexpensive naval wars, on the other hand, could well be waged without allies, and might lead to substantial accretions of lucrative real estate. And, as luck would have it, a naval engagement of some magnitude had occurred just eleven days after the battle of Blenheim. An English force under Sir George Rooke had captured Gibraltar from Spain in July, and the French sent a fleet to drive them away. The August 13 engagement off Malaga was destructive but inconclusive; however, the French fleet drew off during the night and never attempted to engage again for the rest of the war, so, while the battle may have been a draw, it had the long-term effect of a victory. Rooke had the additional merit of being a strong Tory in politics. Philips's poem, therefore, follows the line which St. John himself adopted: there were two victories to celebrate (Dickinson 39). The forces of France had been crushed by land and by sea alike. What better time for England to declare victory and put an end to destructive warfare across Europe from Poland to Spain? Here was a 
message that those paying land tax at four shillings in the pound would heartily endorse: they had received value for what they had paid in the past, and should now look forward to taxation at peacetime rates. Philips thus addresses Queen Anne:

Thou bid'st Thy CHURCHILL go,

Succour the Injur'd Realms, Defeat the Hopes

Of Haughty LOUIS, unconfin'd; he goes

Obsequious, and the dread Command fulfils,

In One Great Day. Again Thou giv'st in Charge

To ROOK, that He should let that Monarch know,

The Empire of the Ocean wide diffus'd

Is Thine; behold! with winged Speed He rides

Undaunted o'er the lab'ring Main, t'assert

Thy liquid Kingdoms; at his near Approach

The Gallic Navies, impotent to bear

His Volly'd Thunder, torn, dissever'd, scud,

And bless the friendly interposing Night.

And, after praising the justice and power of the Queen, he continues:

Thus shall the Nations, aw'd to Peace, extol

Thy Pow'r, and Justice; Jealousies and Fears,

And Hate Infernal banisht shall retire

To Mauretania, or the Bactrian Coasts,

Or Tartary, Engend'ring Discords fell

Amongst the Enemies of Truth; while Arts

Pacific, and Inviolable Love

Flourish in Europe.

(467-74)

Philips's poem promotes the Tory position by removing the battles it celebrates from their strategic contexts; two great victories show that England has won, and the war should now be brought to a close. Despite its title, therefore, Bleinheim distracts attention away from Marlborough and his victory to Rooke and his (allegedly) equally great victory, and ends with a plea to the Queen to bring peace to the nations.

Addison's Campaign, by contrast, delivers exactly what its title promises, which led Joseph Warton to call it that gazette in rhyme. ${ }^{11}$ The Campaign gets the emphasis right: Marlborough was a great general not, as Philips would have it, because he personally slaughtered vast numbers of Frenchmen, but because he created the opportunity to fight the 
battle of Blenheim, and exploited it after it was won. Well-conceived plans are shown being carried out to good effect. Addison's poem, concentrating on actions rather than on persons, makes sound propaganda for Godolphin's Moderation, which in order to work had to downplay personalities and cultivate a team approach. Furthermore, a campaign is by definition but a phase in the prosecution of a war. Addison looks forward to further successful campaigns, not to an immediate peace conference.

In form and style the two poems reflect to some extent their political differences, but, considered as a contrasting pair they participate in a far deeper cultural and literary shift. Philips was a pioneer of post-Miltonic blank verse, preparing the way, especially in his last and longest poem, Cyder, for Thomson and other later poets. Philips's claim to literary fame in 1704 was The Splendid Shilling, first printed in 1701 under the title 'Imitation of Milton'. In its 143 lines, this parody of Milton goes through a variety of relationships with its great original, as Griffin shows in his discussion of it. There is no hint of mock-heroic intention in Bleinheim, however. Philips is serious throughout, and fidelity to Milton lies behind the most obvious fault in his performance. In Johnson's formulation, 'It is indeed the poem of a scholar, 'all inexpert of war'; of a man who writes books from books, and studies the world in a college' (1:317). (Addison, who had carefully avoided battle zones as he travelled home through Italy and southern Germany, was equally 'inexpert of war,' but had not confessed as much as his poem.) The sixth book of Paradise Lost provided Philips with all too apposite a model in the account of the war in heaven, in which the rebel angels invent gunpowder and cannons, and are finally driven out of heaven by the Messiah, who participates only on the third and last day. There were cannons a-plenty on the field of Blenheim, and the flight of many Frenchmen into the fatal waters of the Danube seemed to echo the rush of the doomed angels into 'a spacious gap disclosed/Into the wasteful deep' (VI, 861-62). Miltonic precedent encourages Philips to become too specific in describing cannon-fire and its consequences, and he cannot maintain Miltonic grandeur to the end of the passage (Milton, after all, had the advantage of warriors who were indestructible):

Now from each Van

The brazen Instruments of Death discharge

Horrible Flames, and turbid streaming Clouds

Of Smoak sulphureous, intermixt with these

Large globous Irons fly, of dreadful Hiss,

Singeing the Air, and from long Distance bring

Surprising Slaughter; on each side they fly 
By Chains connex't, and with destructive Sweep

Behead whole Troops at once; the hairy Scalps

Are whirl'd aloof, while numerous Trunks bestrow

Th'ensanguin'd Field....

Before the battle Marlborough's only action is to join his army with Eugene's; the engagement itself has raged for some time and generated mountains of slain before he deigns to participate himself. When he does, he narrowly escapes being hit by a carefully aimed cannonball which is deflected by Destiny; Philips passes in a moment from this realistic detail to a fantasy clearly based on the third-day appearance of Milton's Messiah. It begins:

round his Sacred Head

The glowing Balls play innocent, while He

With dire impetuous Sway deals Fatal Blows

Amongst the scatter'd Gauls.

It ends (omitting the epic simile of Ajax, Laertes's son, and the insulting Trojans):

in Gallic blood again

He dews his reeking Sword, and strews the Ground

With headless Ranks...

\section{Unmanly Dread invades}

The French astony'd; straight Their useless Arms

They quit, and in ignoble Flight confide,

Unseemly Yelling ....

$(206-8 ; 212-15)$

These depictions illustrate the influence of Milton at its most damaging, where it affects content as well as form. When Philips attempts something un-Miltonic in his narrative, such as the remarks of the French soldier before the battle, the epic manner, seriously deployed, obliterates the coarse language of the ranks and so spoils what might have been a vivid moment: 


\section{Thus One}

Jovial his Mate bespoke; O Friend, observe, How gay with all th'Accoutrements of War The Britons come, with Gold well fraught they come Thus far, our Prey, and tempt us to subdue Their recreant Force; how will their Bodies stript Enrich the Victors, while the Vultures sate Their Maws with full Repast!

Elsewhere, Philips can drift into unconscious excess, even anticipating Max Beerbohm's failed poet Enoch Soames by writing 'nor ... not' for 'and' (15; 353-4).

Miltonic expression is matched with heavy classicizing. Philips prefers Latin equivalents to modern geographical names; when he refers to the familiar story of the drowning of the Egyptian army in the refluent waters of the Red Sea (Exodus 14), he obscures it by his use of Latin names. A reference to the city of Memphis turns the Egyptians into 'Memphian Soldiery,' and 'Erythræan Wave' is only recognizable as the Red Sea to those who recall that Strabo and other writers mention a king Erythræus in that region whom Michael Drayton identified with the Biblical Esau or Edom, both names meaning 'red' (232-3). ${ }^{12}$ When he turns from the Bible to modern zoology in a second epic simile anent the French forces which plunged into the Danube, and includes an epic simile of an alligator in 'Paraba, Brazilian Stream,' this unclassical beast is converted into a Grecian 'Hydra' (251ff.). Even the circumstances of composition are classicized: he tells us he wrote the poem at the rural seat of St. John, 'English Memmius' (484). This fulsome compliment Gaius Memmius, an associate of Julius Caesar, was the patron of Catullus and dedicatee of Lucretius' De Rerum Natura - turned out to be unhappily prophetic, since St. John, like Memmius, was to suffer exile for his political miscalculations.

Addison, his career prospects dimmed by the death of William III, had devoted his enforced leisure to literary composition. Already in 1704 he had published upwards of 1300 lines in heroic couplets of translation from Ovid's Metamorphoses, with extensive annotations (1: 63-147); he had also published a 145-line imitation of Milton: 'Milton's Stile Imitated, in a Translation of a Story out of the Third Aeneid' (1:148-53). The story is of the Trojans landing by Mount Aetna, and their pursuit by the Cyclops. Addison's translation is fluent and atmospheric, more spooky than Dryden's version (746-894). This experiment with Miltonics notwithstanding, Addison chose to write The Campaign in pentameter couplets; a medium heroic where required, but flexible enough to 
accommodate mundane matters without bathos. As befits his stance as historian rather than rhetorician, he makes only two explicit allusions to the classics: the first, 'An Iliad rising out of One campaign' (12), implies that this one year of Marlborough's generalship is equivalent to the ten-year Trojan War, and aligns Addison with the Moderns rather than the Ancients. The second (419-24), praising the young Prince of Austria by likening him to Achilles and Aeneas, is appropriate because, as Addison is careful to remind us, the Habsburgs claim descent from the pagan gods (410). Addison does use Latin equivalents for some modern European names: 'Gaul' and 'Gallia' for 'French' and 'France' almost throughout ('France' at 216, however), 'Ausonia' once for Italy, and Latin forms to better fit the verse ('Anna,' 'Germania,' 'Britannia'), and 'Eugenio' always for Prince Eugene. But Addison has plenty of modern names: Moselle, Danube, Maese, Neckar, Schellenberg, Bavarians, Belgian, Donawert, Rhine, Soane, Rhone, Seine, Loire, Memminghem, Augsburg, Ulm, Hocstet, and more. ${ }^{13}$

Addison's subject, Marlborough's 1704 campaign, enables him to give a coherent chronological narrative clearly located in geography: the marches through Flanders and Suabia, the victory at Schellenberg which laid southern Bavaria open, Eugene's abandonment of the crucial defensive lines at Stolhofen to join Marlborough just in time for the decisive battle, the extraordinary collaboration between these commanders and their direction of the battle, the victory and its happy consequences down to the fall of Landau in November - the story makes sense, and each part contributes to the whole. The subject requires Addison to maintain a level of generality appropriate to historical narrative; he is concerned with strategy rather than descriptions of engagements. He is also able to deal gracefully with the defeated Tallard, focussing on the pathos of his situation - defeated, captured, his son killed in action before his eyes. (Tallard was well known in England because of his diplomatic appointment there a few years earlier.) Philips makes Tallard a boastful fool, and does not mention his son. He does, however, mention Marlborough's dead son, the Marquess of Blandford, and Queen Anne's son Prince William of Gloucester, likewise deceased, in a visionary episode in which they drive the spirits of the slain Frenchmen across the Styx; this imitation of Virgil's Æneid VI, 854ff. is an awkward literary gambit since it imagines Christian souls in a classical afterlife. It is perhaps a tactless one too: would Marlborough and Queen Anne care to be reminded that they had recently lost their heirs?

Addison, it is clear, was a more skilful writer and more adept propagandist than Philips; his years of travel gave him an advantage over the fellow Oxonian who had scarcely been out of his college. But the difference is greater than that. Philips writes in the tradition of Latin panegyric, 
very much in the manner of Claudian on Stilicho; ${ }^{14}$ although he writes in English, his devices are those familiar to generations of Renaissance and post-Renaissance students in their academic exercises on set topics: extended epic similes remote from the matter in hand, like the Brazilian crocodile (251-9); complex syntax; exclamations and other rhetorical devices for heightening; and, above all, allusions to Graeco-Roman mythology, history, and literature. Indeed, Edmund Smith, in a fragment of criticism printed at the end of Johnson's life of Philips, expressed the wish that his friend had written the poem in Latin, 'that he might be out of the reach of the empty criticks, who would have as little understood his meaning in that language as they do his beauties in his own' (Johnson 326).

Addison eschews almost entirely the obviously classical features which Philips emphasizes, but a great deal of classical poetry is present by allusion in his verse. In the words of Harold Routh, Addison appealed to his readers because he 'flattered their most treasured boasts - their pride in British freedom, their hero-worship, their love of fighting - in phrases consecrated by Homer, Vergil, Lucan, Statius, Silius Italicus, while the exigencies of the heroic couplet almost necessarily involved 'turns' and 'points' such as the polite age admired' (44). The Campaign is hardly less a poem written from books than is Bleinheim, but Addison's technique is to sublimate his classical content, rather than to flaunt it. A subdued classicism permeates the apparently unvarnished narrative, whereas Philips appears preoccupied with his own bardic activity. That activity is directed in large part to raising the subject to superhuman prowess, depicting Marlborough absurdly as a warrior of Restoration tragedy, a modern Almanzor. For Addison, on the other hand, truly great deeds require only to be described with accuracy; to employ the traditional rhetorical tropes of praise is to betray the inadequacy of the object of praise:

When actions, unadorn'd, are faint and weak, Cities and Countries must be taught to speak; Gods may descend in factions from the skies, And Rivers from their oozy beds arise ...

$(467-70)$

Bleinheim, that is to say, represents classical eloquence, and The Campaign modern politeness, as they are distinguished by Adam Potkay in his recent book, The Fate of Eloquence in the Age of Hume. Potkay is concerned with the middle years of the century, and Addison appears in his book only as an influential prose writer of an earlier generation, but The 
Campaign clearly represents a significant early moment in the development of polite writing.

Addison had made his name at Oxford as a writer of Latin verses. He had figured both as translator, and, through his association with Dryden, as interpreter of Virgil. Then in 1701, during his visit to Italy, he wrote A Letter from Italy (published 1704) to his patron Halifax. Being an epistle, this is appropriately cast in a familiar style as he recounts the scenes of 'classic ground,' but at the end he praises English liberty and William III, breaking off abruptly thus:

My humble muse demands a softer theme,

A painted meadow, or a purling stream;

Unfit for Heroes: whom immortal lays

And lines like Virgil's, or like yours, shou'd praise.

Three years later, in The Campaign, Addison's 'humble muse' took on a hero and made no attempt to write 'lines like Virgil's.' Instead, he claimed that an unadorned style was the fitting vehicle for one whose accomplishments needed no exaggeration:

Fiction may deck the truth with spurious rays,

And round the Hero cast a borrow'd blaze.

MARLBRô's exploits appear divinely bright,

And proudly shine in their own native light;

Rais'd of themselves, their genuine charms they boast,

And those who paint 'em truest praise 'em most.

The Campaign thus asserts that true heroic poetry is historical poetry. This hyperbole simultaneously exalts Marlborough above all ancient epic heroes and abolishes panegyric as traditionally understood. Addison replaces the grand style of traditional epic with the plain style specified earlier for prose by Sprat and Locke. Addison and Philips, just four years apart in age, both clergymen's sons, both classically educated, both Oxford men, thus draw apart, a single but not negligible instance of a great cultural shift. Bleinheim and The Campaign stand on opposite sides of the fault line which separates the modern consciousness from the states of mind which preceded it.

This is not only a literary phenomenon. J. C. D. Clark has recently drawn attention to the long-drawn-out struggle between the traditional, Latinate, European culture of the past, strongly associated with Toryism and Jacobitism, and the new, vernacular, national culture which by the 
early nineteenth century had become dominant in both politics and literature. ${ }^{15}$ The poems on Blenheim of Addison and Philips, it has been argued above, are not 'Whig' and 'Tory' poems in the ordinary sense, but poems equally sponsored by senior ministers of the Crown to celebrate military successes which they had collectively helped to bring about. The primary political label for both must be 'Moderation,' though each is coloured by the more sharply defined extremes of the political spectrum, and their existence reflects the Whig and Tory rivalry that would eventually destroy Godolphin's ministry. In the broader context supplied by Dr. Clark, however, the traditional party distinction takes on a new significance. Bleinheim and The Campaign document one small area of the great divide between ancient and modern consciousness. They take on a new fascination as we explore the intricacies of eighteenth-century cultural politics.

JOHN D. BAIRD

Victoria College, University of Toronto

\section{Notes}

1 My count covers the twelve months from the date of the battle, August 2, 1704 (O.S.). Unless otherwise noted, all dates are given in Old Style. In revising this paper I have benefited from discussions with Dr. Mark McDayter.

2 Horn, 'Addison's Campaign.' Smithers cites Horn's article, but retains Budgell's more vivid details.

3 Locke died October 28, 1704; it was his death, and not, as Tickell says, his 'removal ... to the council of Trade" which created the vacancy (Addison 1: xvii). Addison's acknowledgement of the appointment makes no reference to his poem (Letters 50). The appointment's being made on the strength of an incomplete poem is important: Godolphin would hardly have given so generously without some sense of what he was to get for his money; and it explains the bitter comments by Defoe and others on Addison's 'Venal Wit,' for a patron's reward should be a gift upon receipt of a completed work, not a payment to ensure completion of work in progress. See Horn, 'Addison's' 894-5, and William Shippen (Ellis 632), who explicitly links Addison with Poet Laureate Nahum Tate, whose hireling pen did not produce The Triumph until January 18 (Horn, Marlborough 116).

4 For Marlborough's reception, see Churchill 1: 914-19. The poem mentions the capitulation of Landau (November 17, O.S.), and the first edition shows signs of hasty printing, which suggest that the first announcement of imminent publication was premature (Horn, 'Early').

5 For St. John's frequent visits to Bucklebury on family business before the Parliamentary session began at the end of October, see his letters to T. Coke (Oct. 10, 1704) and Sir W. Trumbull (Oct. 1704), Historical Manuscripts Commission, 
Cowper MSS, I. iii. 49, and Downshire MSS, I. ii. 836. I owe these references to Dickinson 39.

6 See William Shippen's poem Moderation Display'd, with helpful introduction (Ellis 19-42). The restriction of Poems on Affairs of State to satirical verse unfortunately excludes both Bleinheim and The Campaign .

7 Philips's words quoted by William Brome (Philips xxii), 'I could not help it, Mr. Secratorry Harley made me write it,' suggest that Harley was the instigator but preferred to remain behind the scenes, and had his junior, St. John, appear publicly as the poem's sponsor.

8 Philips also received a present from Godolphin, amount not specified, on account of the favourable references to him in the poem (Philips xxii).

9 It is probable that publication was delayed until after the crucial vote on the tack had taken place (November 28). Had the tackers won, the poem would have required a different conclusion. Ellis explains the tack clearly (43-44).

10 Unfortunately Downie's excellent study does not mention either Bleinheim or The Campaign.

11 Addison would not have taken this comment amiss; he was interested in medals and coins because they were 'a kind of Gazette' (Gámez 488).

12 The historical Mediterranean city of Erythrae is a red herring, but how many readers would know that?

13 Boileau complains of the difficulty of working Flemish and German place-names into mellifluous verse in Épitre IV: Au Roi; Prior mocks him for this in his poem on Blenheim, A Letter to M. Boileau (1: 220-6).

14 Addison quotes Claudian on his title-page, but wisely restricts his role to this epigraph.

15 While Cannon's temperate assessment of Johnson's alleged Jacobitism is preferable to Clark's excessively partisan claims, both historians have done a real service by directing attention to the interrelations of religion and politics and literature throughout the eighteenth century.

\section{Works Cited}

Addison, Joseph. The Letters of Joseph Addison. Ed. Walter Graham. Oxford: Clarendon P, 1941.

. The Miscellaneous Works of Joseph Addison. Ed. A. C. Guthkelch. 2 vols. London: Bell, 1914.

Beerbohm, Max. Seven Men and Two Others. Oxford: Oxford UP, 1980.

Cannon, John. Samuel Johnson and the Politics of Hanoverian England. Oxford: Clarendon P, 1994.

Churchill, Winston. Marlborough: His Life and Times. 4 vols. in 2. London: Harrap, 1947.

Clark, J. C. D. Samuel Johnson: Literature, Religion, and English Cultural Politics from the Restoration to Romanticism. Cambridge: Cambridge UP, 1994. 
Dickinson, H. T. Bolingbroke. London: Constable, 1970.

Downie, J. A. Robert Harley and the Press: Propaganda and Public Opinion in the Age of Swift and Defoe. Cambridge: Cambridge UP, 1979.

Ellis, Frank H., ed. Poems on Affairs of State: Augustan Satirical Verse, 1660-1714. Volume VII: 1704-1714. New Haven: Yale UP, 1975.

Foxon, D. F. English Verse 1701-1750. 2 vols. Cambridge: Cambridge UP, 1975.

Gámez, Luis Rene. 'The 'Angel' Image in Addison's The Campaign.' Notes and Queries (Dec. 1986): 486-9.

Griffin, Dustin. 'The Bard of Cyder-Land: John Philips and Miltonic Imitation.' SEL 24 (1984): 441-60.

Historical Manuscripts Commission. The Manuscripts of the Earl Cowper, K. G. 3 vols. London: HMSO, 1888-89.

. The Manuscripts of the Marquess of Downshire. Papers of Sir William Trumbull. 1 vol. in 2. London: HMSO, 1924.

Horn, Robert D. 'Addison's Campaign and Macaulay.' PMLA 63 (1948): 886-902.

.'The Early Editions of Addison's Campaign.' Studies in Bibliography 3 (1950-51): 256-61.

. Marlborough: A Survey. Panegyrics, Satires, and Biographical Writings, 1688-1788.

New York: Garland, 1975.

Johnson, Samuel. Lives of the English Poets. Ed. G. B. Hill. 3 vols. Oxford: Clarendon P, 1905.

Philips, John. The Poems of John Philips. Ed. M. G. Lloyd Thomas. Oxford: Blackwell, 1927.

Potkay, Adam. The Fate of Eloquence in the Age of Hume. Ithaca and London: Cornell UP, 1994.

Prior, Matthew. The Literary Works of Matthew Prior. Ed. H. B. Wright and M. K. Spears. 2nd ed. 2 vols. Oxford: Clarendon P, 1971.

Routh, Harold. 'Steele and Addison.' The Cambridge History of English Literature, ed. A. W. Ward and A. R. Waller. Vol. 9. Cambridge: Cambridge UP, 1912: 26-65.

Sewell, George. Poems Attempted in the Style of Milton by Mr. John Philips ... With His Life by Dr. Sewell. 10th ed. London, 1744.

Smithers, Peter. The Life of Joseph Addison. Oxford: Clarendon P, 1954.

Steele, Richard. The Occasional Verse of Richard Steele. Ed. Rae Blanchard. Oxford: Clarendon P, 1952.

Warton, Joseph. An Essay on the Genius and Writings of Pope. 2 vols. London: 1782; rpt. Farnborough, Hants: Gregg, 1969. 